ISSN 1991- 8690

Website: http://jsci.utq.edu.iq
الترقيم الاولي • 1991 - 1999

Email: utjsci@utq.edu.iq

\title{
The efficiency of drinking -water-treatment processes in removing of some PAHs compounds from water in Erbil city-Iraq
}

\author{
*Awaz B. Mohammed ** Siraj M.A.Goran **** Maysoon M. Al-Taee \\ * College of Science /Kirkuk Univ. ** College of science /Salahaddin Univ \\ *** College of Science/Babylon Univ.
}

\begin{abstract}
$\underline{\text { Abstract }}$
water samples at each treatment step of drinking water treatment plants(DWTPs) in Erbil city were collected to study sixteen PAHs componds listed by USEPA as priority pollutants and determine the efficiency of each process in removal of PAHs .The highest values of $(0.313 \mu \mathrm{g} / \mathrm{L}$ and $0.233 \mu \mathrm{g} / \mathrm{L}$ )were recorded for Benzo(k)flouranthene in DWTP 1 and 2(Efraz 1,2)during June 2008 in raw water, while the highest value of $0.174 \mu \mathrm{g} / \mathrm{Lwas}$ recorded for Acenaphtheen and flourene during june 2008 in raw water at Efraz 3.No values were recorded for Low molecular weight PAHs during the study periods at DWTPs in some treatment steps. The lowest values in the tap water(treated water)which reffered to the efficiency of treatment processes in removing of PAHs from the source water. mean concentration of Total PAHs compounds which ranged between $(0.150-1.43 \mu \mathrm{g} / \mathrm{L}),(0.081-1.462 \mu \mathrm{g} / \mathrm{L})$ and $(0.080-0.0941$ were recorded at Efraz 1, 2 and 3 during June 2008 and April 2009 in in source water and tap water respectively. the removing percentage of totl PAHs were $(84 \%, 90 \%$ and $85 \%)$ and $(83 \%, 92 \%$ and $86 \%)$ were recorded at Efraz 1,2,3 during June2008 and April 2009 respectively. The highest values were recorded for 5ring (BbF,BkF.BaP,DBA)PAHs at Efraz and 2 and 4-ringPAHs(Flur,Py,BaA and chry)at efraz 3 .
\end{abstract}

Key word: PAHs ,Drinking water ,PAHs removing 


\section{Introduction}

Among wide variety of chemicals, Polycyclic Aromatic Hydrocarbons (PAHs) are of particular concern as a widespread ,persistent and toxic contaminants in the environment (1).They are commonly reffered to a large class of organic compounds throughout the environment and generated by natural and anthropogenic activity $(2,3,4)$.Concidering their mutagenic, carcinogenic and teratogenic properties and their potential hazard to human health and natural ,they have attracted agood deal of attention and carcinogenic PAHs are all byond to high molecular weight PAHs ,having four or more rings $(5,6,7)$.Water pollution by PAHs compounds may be associated with the anthropogenic activities that represent the major sources of PAHs in addition to the natural sources(2).There are several factors which play essential role in removing of PAHs from water.It is found that water treatment processes including chlorination plays important role in removing PAHs from drinking water.chlorine react with PAHs to produce Quinones and polychlorinated aromatics (8). The effectiveness of these treatment varied widely within and among classes of compound.Some hydrophobic compounds as PAHs were strongly oxidized by free chlorine while some hydrophilic were partly removed through adsorption processes(9).Because there is no available data about the PAHs compounds listed by USEPA as priority pollutants ,the aim of the present study is collection of water sample at each treatment step of drinking water treatment plant(DWTP) in Erbil city and determine the efficiency of each process in removal of PAHs.

\section{Description of Drinking water- Treatment plants and sample collection:}

The upper Zap of Tigris river is provide water source for DWTP in Erbil city (Efraz 1 established in 1968), ( Efraz 2 established in 1982) and (Efraz 3 that build up in 2004)..The DWTP treated $\mathrm{m}^{3}$ and provided about $10500 \mathrm{~m}^{3} / \mathrm{hr}$ and most of water is provided from efraz $3(8500 \mathrm{~m} 3 / \mathrm{hr})$. Both E 1 and E3 are located to the north west of erbil city within Efraz Kamal village ,while E2 is located in Erbil city at the right side of main way of erbil-Inkawa road.

Water samples at each Efraz plant were collected in the following points 1- Raw water (low left).

2- Flash mixer (After addition of alum , polymer and Chlorine)

3- Clarifier (After sedimentation)

4- Filteration unit (After filteration)

5- High left (Tap water) after asecond chlorination and ready to be distributed

Scheme(1): Show DWTP and sample point locations

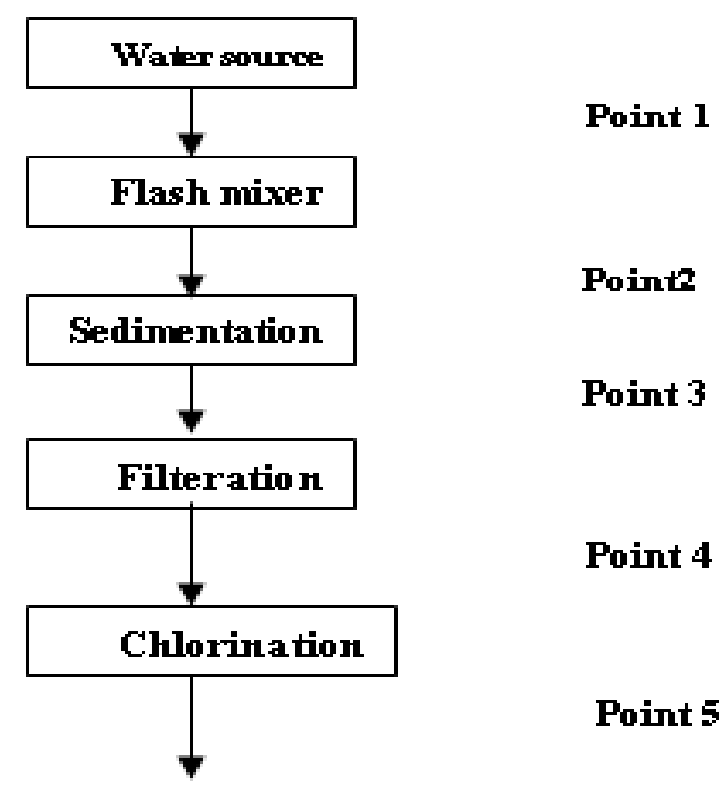


Sample collection at water treatment sites in each efraz plant were conducted during March and June 2008. Two liter of water sample at each site were collected using pre- cleaned dark glass bottle containing sixty $\mathrm{ml}$ of CCL4,then closed with aluminium foiled lined cap.

Material and methods:

\section{Extraction of PAHs from water :}

The PAHs compounds in water were determined using Liquid - Liquid extraction method as described by UNEP ,1989(10).On returning back to the laboratory, bottle sample was shaked for one hour,then the contents of the bottle were transferred to seperation funnel and allow the organic layer to separate from water phase for a minimum of ten minutes . Extraction procedure was repeated with another $60 \mathrm{ml}$ of $\mathrm{CCl} 4$ and the combining exracts were transferred into the flask. The organic extract was then evaporated to dryness by rotary evaporator $\left(50^{\circ} \mathrm{C}\right.$ bath temperature and $10^{\circ} \mathrm{C}$ temperature of water refrigerator circulator).Because the extract contains complex components, the clean up procedure was undertaken by column chromatography using deactivated silica gel packed in glass column $(250 \mathrm{~mm} \times 15 \mathrm{~mm} \quad$ 1.D. $)$. The column was pre-eluted with $10 \mathrm{ml}$ of Hexan, then the extract was passed through the column followed by elution with $50 \mathrm{ml}$ Benzene as described by Maskaoui et al., 2002(11). After evaporation step, the residue was dissolved with $5 \mathrm{ml}$ Acetonitrile, then concentrated to $1 \mathrm{ml}$ under gentle $\mathrm{N} 2$ .The exract was stored at $\left(-20^{\circ} \mathrm{C}\right)$ until analysis by High Performance Liquid Chromatograph HPLC .

\section{Calibration :}

A standard solution of sixteen USEPA priority PAHs was obtained from Sigma-
Aldrich company as PAHs calibration mixture in order to compare the retention times and spectra of compounds in the standard with those in the sample.The standard calibration contain the compounds:

Acenaphthalene, Naphthalene, Fluorene, Phenanthrene, Anthracene, Fluoranthene, Pyrene, Benzo(a)anthracene, Chrycene, Benzo(b)Fluoranthene, Fuoranthene, Benzo(k) Dibenzo(a,h) anthracene, Benzo(ghi) Perylene and Indeno(1,2,3-cd) pyrene.

\section{PAHs analysis :}

The PAHs extracts of water samples were analyzed by HPLC. The mobile phase was HPLC-grade acetonitrile and Distilled water in a linear gradient program .Ten $\mu l$ of sample was injected into a stationary phase capillary column with a dimension of $(15 \mathrm{~cm} \times 4.6 \mathrm{~mm}$ ID) and determined with UV detector at 254 $\mathrm{nm}$. The flow rate of mobile phase was kept at $1.5 \mathrm{ml} / \mathrm{min}$. The peak in the chromatogram were identified by comparing of the retention time and spectra of standard with those in the sample

Statistical Analysis:

Analysis of variance (ANOVA) on concentrations of PAHs compounds were statistically significant or not among the DWT plants(Efraz1,2 and 3).Independent $T$ test was used to indicate which concentrations were similar to or significantly different from others between the two study periods.Removing Percentage of PAHs compounds by each water-treatment process by using the formula:

$(\mathbf{1}-[\mathrm{C} / \mathrm{CO}] * \mathbf{1 0 0})$

$\mathrm{C}$ is the concentration in the treatment step, while $\mathrm{C} 0$ is the concentration in preceding treatment step.total percentage 
removing was calculated with $\mathrm{C}$ as concentration in finished water (Tap water) and $\mathrm{C} 0$ as concentration in source water [Stackelberg et el., 2007](9).

\section{Results:}

Samples of water from three Drinkingwater -treatment plants DWTP(Efraz1,2 and 3) in erbil city were analysed for sixteen PAHs compounds listed by USEPA as priority pollutants were (NaP,ACPY.AcP\&Flu,Phen,Anth,Flur,

Py, BaA,Chry,BbF, BkF, BaP, DBA,BghiP, and IND).The concentration of sixteen PAHs which were detected in the source water (Raw water) and each step of treatment process(after flash mixer, after clarifying (sedimentation ) and after second chlorination (Tap or finished water) were showed in (Figs.1$3)$. The highest values of $0.313 \mu \mathrm{g} / \mathrm{L}$ and $0.233 \mu \mathrm{g} / \mathrm{L}$ )were recorded for Benzo(k)flouranthene in DWTP 1 and 2(Efraz 1 and 2)during June 2008 in raw water, while the highest value of 0.174 $\mu \mathrm{g} / \mathrm{Lw}$ as recorded for Acenaphtheen and flourene during June 2008 in raw water at Efraz 3.No values were recorded for Low molecular weight PAHs during the study periods at DWTPs in some treatment steps. There is a fluctuation in the concentrations of other PAHs compounds at DWTPs in the points of treatment steps. The lowest values in the tap water which reffered to the efficiency of treatment processes in removing of PAHs from the source water. The results reffered to the mean concentration of Total PAHs compounds which ranged between (0.150-1.43 $\mu \mathrm{g} / \mathrm{L}), \quad(0.081-1.462 \mu \mathrm{g} / \mathrm{L})$ and $(0.080-$ 0.0941were recorded at Efraz 1, 2 and 3 during June 2008 in source water and during April 2009 in tap water respectively.From the sum of( 15,13 PAHs), (16,13 PAHs), (14,11 PAHs) ,only (5 , 6 PAHs),(11, 6 PAHs), (7, 6 PAHs) compounds were removed from the source water at Efraz 1, 2 and 3 during June 2008 and April 2009 respectively which reffered to the efficiency of drinking water treatment processes for removing of PAHs from water(table 2). Both DBA and BghiP were detected in finished water at DWTPs during the study periods .As related with total PAHs , the removing percentage were $(84 \%, 90 \%, 85 \%)$ and $(83 \%, 92 \%, 86 \%)$ were recorded at Efraz 1,2,3 during June2008 and April 2009 respectively.The DWTP processes have the efficiency for removing PAHs from the water ,however some time there was the increasing in the concentrations of pAHs from one treatment step to other .The highest values of 0.62 and 0.60 $\mu \mathrm{g} / \mathrm{L}$ were recorded for 5-ring PAHs compounds (BbF,BkF.BaP,DBA) at Efraz1 and 2 during June 2008 in tap water and source water respectively., while the highest value of $0.35 \mu \mathrm{g} / \mathrm{Lwas}$ recorded for 4-ring PAHs (Flur,Py,BaA,chry)during june 2008 in tap water at Efraz 1.No values were recorded for 2-ring PAHs(NaP,AcpY),3ringPAHs(AcP,Flur.Phen,Ant), 4-ring PAHs(Flur,Py,BaA,chry) in tap water (finished water) at efraz1 during April 2009.Also 2-ring PAHs and 2 ,4ringPAHs were not detected at Efraz 2 and 3 respectively(table 3 ). The results reffered to the values ranged between (7.08-8.43), (373-471 $\mu \mathrm{sm} / \mathrm{cm})$, (92$194 \mathrm{mg} / \mathrm{L}), \quad(84-184 \mathrm{mg} / \mathrm{L}), \quad$ (3.2$12.8 \mathrm{mg} / \mathrm{L}),(\mathrm{ND}-2.6 \mathrm{mg} / \mathrm{L}),(16-25.3 \mathrm{mg} / \mathrm{L})$ were recorded for $\mathrm{pH}$, Electrical Conductivity EC ,alkalinity, total hardness,calcium, Dissolved Oxygen D.O.,BOD5 and chloride ion respectively.(Table 4).According to the results of ANOVA table, no significant differences $(\mathrm{P}>50)$ were recorded for 
PAHc concentration PAHs among DWTPs (Efraz1,2,3) during the study period.As related with time of sample collection .The Concentration of pAHs were significancy similar between time 1(June 2008) and time 2(April 2009) with exception of highest value recorded for DBA at efraz land efraz 2during June 2008.

\section{Discussion:}

The results of the study reffered to the high concentration of High Molecular Weight PAHs HMW-PAHs(4,5,6-ringPAHs)in comparison to Low molecular wighet PAHs LMW-PAHs(2 and 3-ring -PAHs )in water source .The results reffered to no value or very low concentration of some Low molecular wighet PAHs in finished water in comparison to high molecular wighet PAHs( (Figs. 1-3). This may be related with Low water solubility of HMWPAHs and high partition coefficient (Kow) and high volatility of LMWPAHs $(14,15)$ and interaction of several processes as volatilization of Low Molecular Weight PAHs(LMWPAHs), bioconcentration, sedimentation ,solubilization and biodegradation(2)..The results of this study indicated that the drinking water treatment processes play essential role in removing of detectable levels of PAHs from raw water (water source)(Table1 and 2) .The effectiveness of Drinking Water Treatment Plant(DWTP)in removing of organic compounds as PAHs depending upon several factors including quality of water source (16), the type and mode of operation of each treatment process and physiochemical properties of PAHs compound themselves $(17,18)$. The results reffered to the completely removing of most compounds in drinking water or finished water, however the concentration of some PAHs decrease by one process and increace in the followed step in all three DWT plants (Efraz 1,2 and 3) that depent on the effieciency of each process for removing (effieciency of operation) .There are two major sources of PAHs in drinking or tap water, contamination of raw water supplies from natural and man-made sources and leachate from coal tar and asphalt linings in water storage tanks and distribution lines, therefore the presence of PAHs in water may from PAH-containing material in water storage and distribution system(19,20)). The main processes in DWTP include addition of Chlorine,polymer,and alum in flash mixer for coagulation and increasing the adsorption of suspended organic particulates to be settled ; Clarification or sedimentation that will reduce the remining suspended particulates to be delivered to sludge bed ;filtreation (filter units or system) ; injection of chlorine before finishing the treatment of water .This may be a method of ensuring the bacteriological quality and controlling disease as appear from the results that each process had a role in redusing the PAHs level in drinking water to non affected levels. There are several factors in removing of PAHs from water.the main mechanism include the oxidation of some PAHs as fluoranthene and pyrene were due to the oxidation with chlorine $(9,21)$. The results reffered to the non significant variation in concentration of PAHs compounds among the three treatment plants (Efraz,1,2,3).This may due to the same water source of drinking water and expose to the similar sources of PAHs and the effieciency of the operation of each treatment process . The results reffered to the fluctuation in the concentration of some PAHs compounds 
during the period of study and high values were recorded during june 2008 this may be due to increace of atmospheric deposition to source water during that time $(2,22)$.also the water flow may affected the leval of PAHs in water (1). The concentration of PAHs exceeding $10 \mu \mathrm{g} / \mathrm{L}$ was considered to be heavily contaminated (WHO,1998)(23).the results reffered to the values of total PAHs in source water between $(0.150-1.43 \mu \mathrm{g} / \mathrm{L}), \quad(0.081-$ $1.462 \mu \mathrm{g} / \mathrm{L})$ and $(0.080-0.0941)$ were recorded at Efraz 1, 2 and 3 during June 2008 in source water and during April 2009 in tap water respectively.this reffered to non contaminated water. In general ,the most samples of surface water contain individual PAHs at level of up to $0.05 \mu \mathrm{g} / \mathrm{L}$ but high polluted water had concentration of up $6 \mu \mathrm{g} / \mathrm{L}$.As related with the individual $\mathrm{PAHs}$ in finished water ,some PAHs as Chry,Flur, $\mathrm{BbF}, \mathrm{BkF}, \mathrm{BaP}, \mathrm{DbA}, \mathrm{BghiP}$ and IND were detected in low levels ,however the DWTP should be monitored because of the carcinogenic properties of these cmpounds . BaP considered to be probable human carcinogen .according to the USEPA,2007(24), should not be present in the concentration above 0.2 $\mu \mathrm{g} / \mathrm{L}$ as maximum contaminant level(MCL).Some Physiochemical properties of Water under study were also determined (table 4) and within the standard range . 


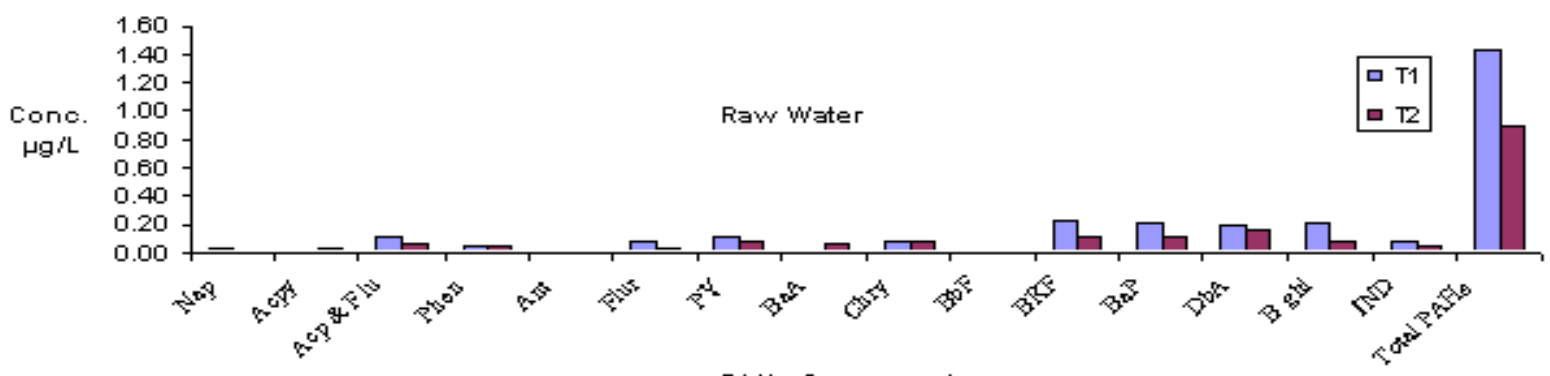

PAHs Compounds
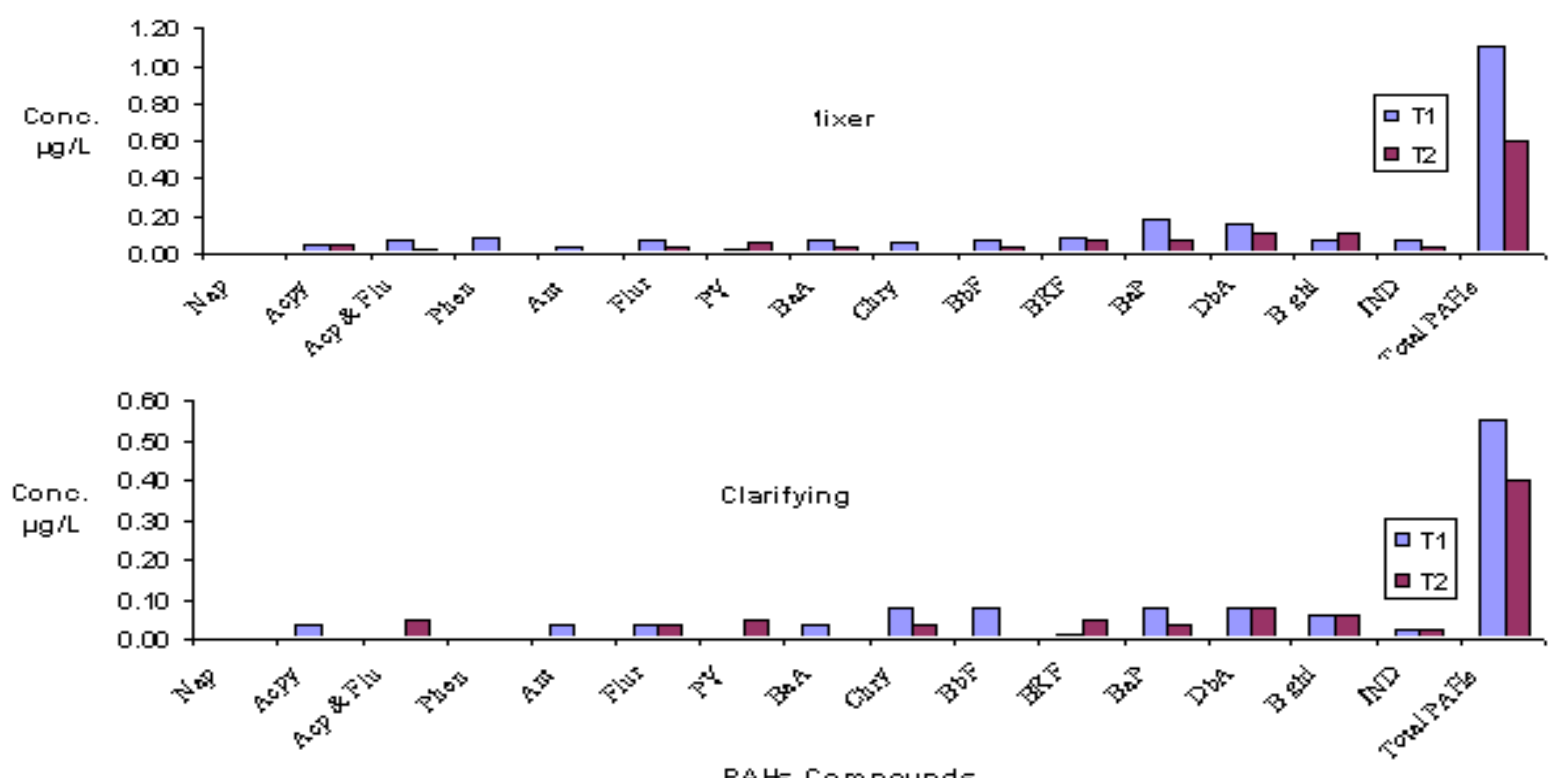

PAHs Compounds

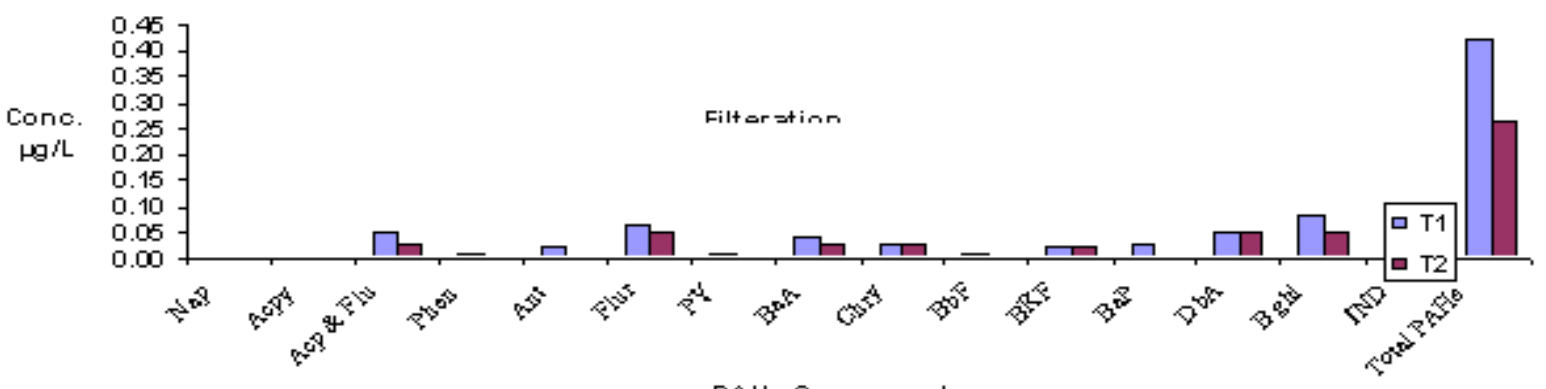

PAHs Compounds

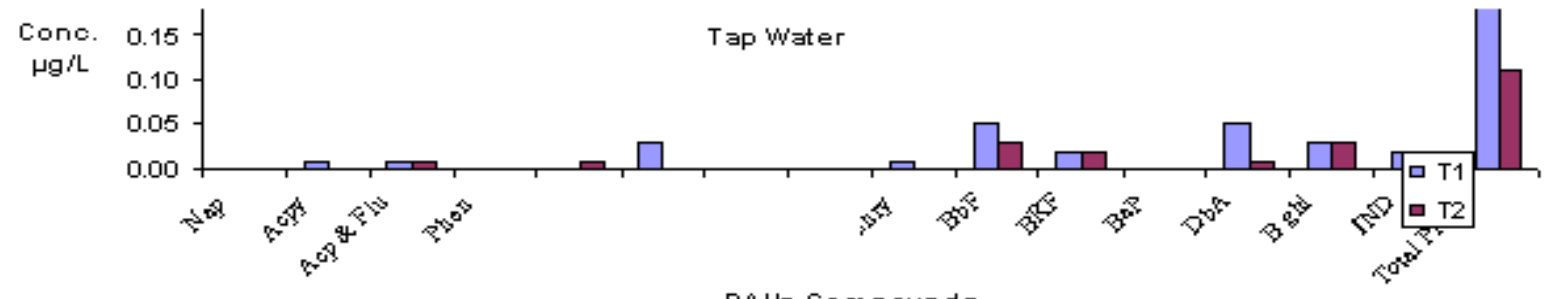

PAHs Compounds

Figure (1) Mean Con. of PAHs Compounds in Drinking water treatment plant DWTP ( Efraz 1) during $\mathrm{T} 1$ and $\mathrm{T} 2$ 

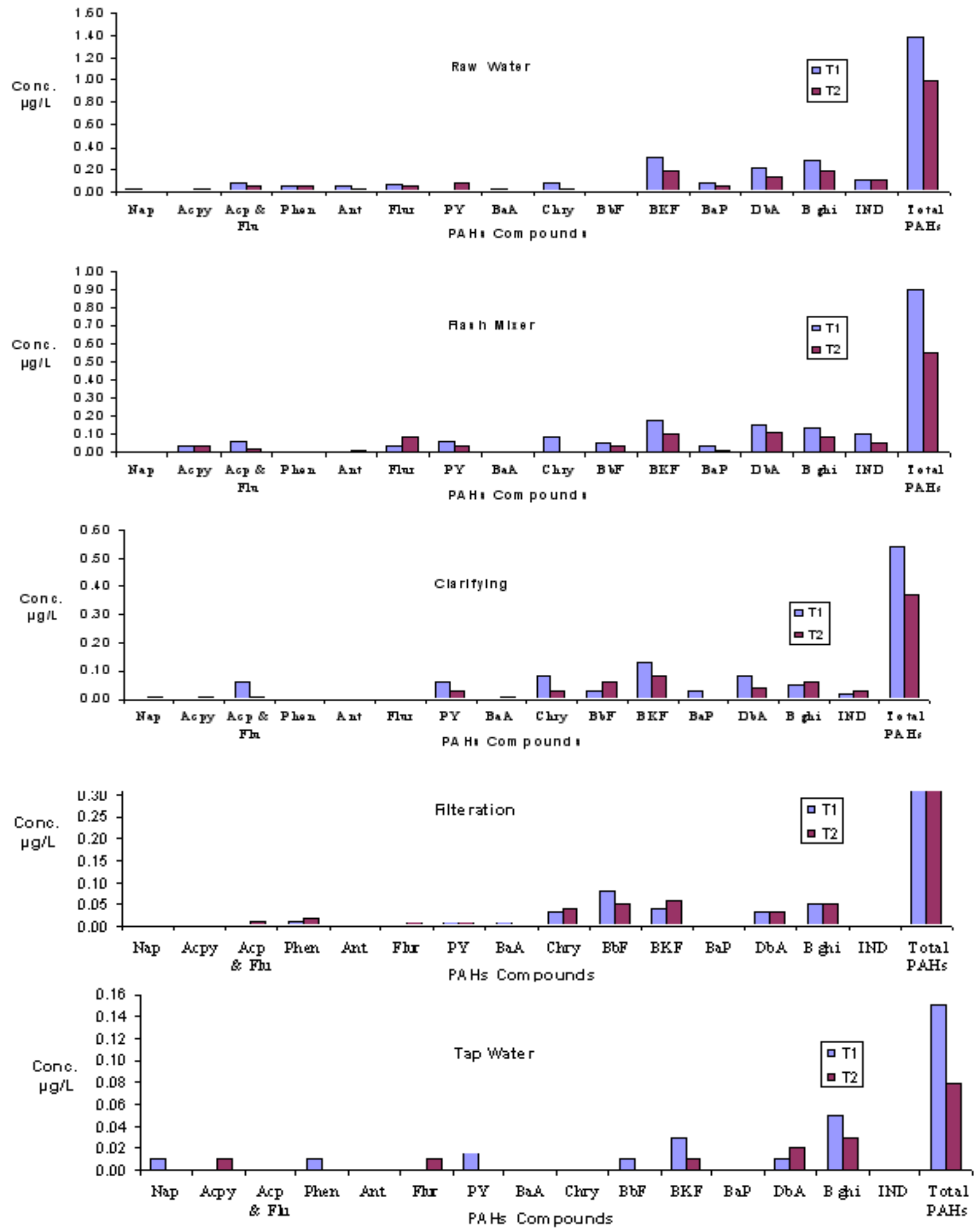

Figure(2) Mean Con. of PAHs Compounds in Drinking water treatment plant DWTP(Efraz 2) during $\mathrm{T} 1$ and $\mathrm{T} 2$ 

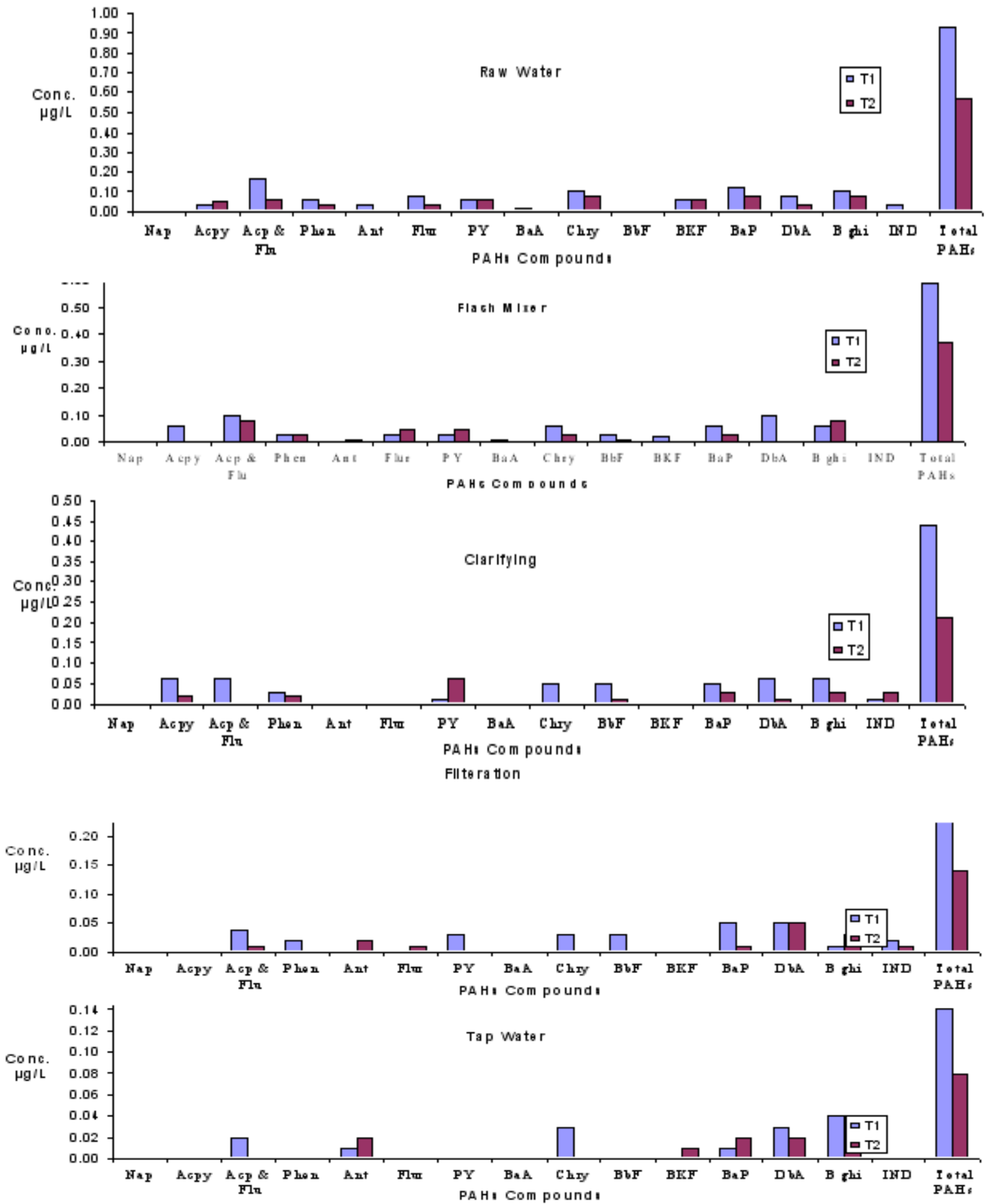

Figure(3) Mean Con. of PAHs Compounds in Drinking water treatment plant DWTP(Efraz3)during T1 and T2 
Table(1):Removing percentage of PAHs compounds in drinking water treatment plants (Efraz 1,2,3)during the study period

\begin{tabular}{|c|c|c|c|c|c|c|c|c|}
\hline & \multicolumn{2}{|c|}{ Flash mixer } & \multicolumn{2}{|c|}{ Clarifying } & \multicolumn{2}{|c|}{ Filteration } & \multicolumn{2}{|c|}{ Tap water } \\
\hline & $\mathrm{T} 1$ & T2 & T1 & $\mathbf{T 2}$ & T1 & $\mathbf{T 2}$ & T1 & $\mathbf{T 2}$ \\
\hline \multicolumn{9}{|c|}{ Efraz 1} \\
\hline NaP & - & - & - & - & - & - & - & - \\
\hline Acpy & $100 \%$ & & $\%$ Yo & $100 \%$ & & & $100 \%$ & $100 \%$ \\
\hline Acp \&Flu & $27 \%$ & $67 \%$ & $100 \%$ & - & - & $\% \varepsilon$ & $\% \% \varepsilon$ & $\% T V$ \\
\hline Phen & - & $\% 1 \ldots$ & - & & - & - & $100 \%$ & $100 \%$ \\
\hline Ant & & - & - & - & \% & - & $\% 1 \ldots$ & - \\
\hline Flur & $62 \%$ & - & $50 \%$ & - & - & - & $62 \%$ & $100 \%$ \\
\hline $\mathbf{P y}$ & $\% \wedge r$ & $37 \%$ & $100 \%$ & - & - & $100 \%$ & - & - \\
\hline $\mathbf{B a A}$ & - & $\% 0$. & $\% 0$ & $\% 1 \ldots$ & - & - & $100 \%$ & $\% 1 \ldots$ \\
\hline Chry & $\% r v$ & $\% 1 \ldots$ & - & - & $\%$ & - & $\% \wedge \mathrm{V}$ & $100 \%$ \\
\hline BbF & - & - & $\%$ & $\% 1 \cdots$ & - & - & - & - \\
\hline BkF & $61 \%$ & $27 \%$ & $11 \%$ & $\% r V$ & $\% \vee 0$ & $\%$ \%. & $\% \% 91$ & $\% \wedge r$ \\
\hline BaP & $14 \%$ & $27 \%$ & $56 \%$ & $62 \%$ & $62 \%$ & $100 \%$ & $100 \%$ & $100 \%$ \\
\hline DbA & $\% 11$ & $33 \%$ & $50 \%$ & $27 \%$ & $37 \%$ & $37 \%$ & $72 \%$ & $94 \%$ \\
\hline BghiP & $71 \%$ & - & - & $\% 45$ & - & $\% \backslash V$ & $\% \wedge 7$ & $\% \pi r$ \\
\hline IND & - & $\% \varepsilon$. & $\% \vee 0$ & $\%$ & $\% 0$ & $\% 1 \ldots$ & $\% \vee 0$ & $\% 1 \ldots$ \\
\hline Total PAHs & $23 \%$ & $32 \%$ & $50 \%$ & $31 \%$ & $23 \%$ & $\% \wedge 3$ & $\% \wedge \Sigma$ & $83 \%$ \\
\hline \multicolumn{9}{|c|}{ Efraz 2} \\
\hline NaP & - & $100 \%$ & - & - & - & $100 \%$ & $50 \%$ & \\
\hline Aсpy & - & - & $100 \%$ & $67 \%$ & - & $100 \%$ & $100 \%$ & - \\
\hline Acp \&Flu & $25 \%$ & $60 \%$ & - & $50 \%$ & $100 \%$ & - & $100 \%$ & $100 \%$ \\
\hline Phen & $100 \%$ & $100 \%$ & - & - & - & - & $80 \%$ & $100 \%$ \\
\hline Ant & $100 \%$ & $67 \%$ & - & $100 \%$ & - & - & $100 \%$ & $100 \%$ \\
\hline Flur & $57 \%$ & - & $100 \%$ & - & - & - & $100 \%$ & $83 \%$ \\
\hline $\mathbf{P y}$ & $40 \%$ & $63 \%$ & - & - & $17 \%$ & - & $70 \%$ & $100 \%$ \\
\hline $\mathbf{B a A}$ & $100 \%$ & $100 \%$ & - & - & - & $100 \%$ & $100 \%$ & $100 \%$ \\
\hline Chry & - & $100 \%$ & - & - & $63 \%$ & - & $100 \%$ & $100 \%$ \\
\hline $\mathbf{B b F}$ & - & - & $40 \%$ & - & & - & - & - \\
\hline BkF & $42 \%$ & $44 \%$ & $28 \%$ & $\%$ \%. & $69 \%$ & $25 \%$ & $90 \%$ & $94 \%$ \\
\hline BaP & $\%$ & $83 \%$ & & $\% 1 \ldots$ & $\% 1 \ldots$ & & $\% 1 \ldots$ & $\% 1 \ldots$ \\
\hline DbA & $\%$ Yq & $15 \%$ & $47 \%$ & $64 \%$ & $63 \%$ & $25 \%$ & $95 \%$ & $84 \%$ \\
\hline BghiP & $\% 0 \leq$ & $\% 07$ & $\%$ \% & $\%$ Yo & & $\%$ IV & $\% \wedge r$ & $\%$ \% \\
\hline IND & - & $50 \%$ & $80 \%$ & $40 \%$ & $100 \%$ & $100 \%$ & $100 \%$ & $100 \%$ \\
\hline Total PAHs & $39 \%$ & $44 \%$ & $40 \%$ & $33 \%$ & $41 \%$ & $8 \%$ & $90 \%$ & $92 \%$ \\
\hline \multicolumn{9}{|c|}{ Efraz3 } \\
\hline NaP & - & - & - & - & - & - & - & - \\
\hline Acpy & - & $100 \%$ & - & - & $100 \%$ & $100 \%$ & $100 \%$ & $100 \%$ \\
\hline Acp \&Flu & $41 \%$ & - & $40 \%$ & $100 \%$ & $33 \%$ & - & $88 \%$ & $100 \%$ \\
\hline Phen & $40 \%$ & $25 \%$ & - & $33 \%$ & $33 \%$ & $100 \%$ & $100 \%$ & $100 \%$ \\
\hline Ant & $100 \%$ & - & - & $100 \%$ & - & - & $67 \%$ & - \\
\hline Flur & $62 \%$ & - & $100 \%$ & $100 \%$ & - & - & $100 \%$ & $100 \%$ \\
\hline $\mathbf{P y}$ & $40 \%$ & $17 \%$ & $67 \%$ & - & - & $100 \%$ & $100 \%$ & $100 \%$ \\
\hline $\mathbf{B a A}$ & - & - & $100 \%$ & - & - & - & $100 \%$ & - \\
\hline Chry & $40 \%$ & $62 \%$ & $17 \%$ & $100 \%$ & $40 \%$ & - & $70 \%$ & $100 \%$ \\
\hline $\mathbf{B b F}$ & - & - & - & - & $40 \%$ & $100 \%$ & - & - \\
\hline BkF & $67 \%$ & $100 \%$ & $100 \%$ & - & - & - & $100 \%$ & $83 \%$ \\
\hline BaP & $\% 0$ & $63 \%$ & $17 \%$ & - & - & $67 \%$ & $92 \%$ & $75 \%$ \\
\hline $\mathbf{D b A}$ & - & $100 \%$ & $40 \%$ & - & $17 \%$ & - & $62 \%$ & $33 \%$ \\
\hline BghiP & $40 \%$ & - & - & $63 \%$ & $83 \%$ & - & $60 \%$ & $88 \%$ \\
\hline IND & $100 \%$ & - & $-{ }^{-3}$ & - & - & $67 \%$ & $100 \%$ & - \\
\hline Total PAHs & $37 \%$ & $42 \%$ & $19 \%^{5}$ & $36 \%$ & $42 \%$ & $33 \%$ & $85 \%$ & $86 \%$ \\
\hline
\end{tabular}


Table(2) :The range and Mean \pm S.D.of PAHs compound recorded at DWTP(Efraz 1,2,3)during the study period

\begin{tabular}{|c|c|c|c|}
\hline PAHs compounds & Efraz 1(E1) & Efraz 2(E2) & Efraz 3(E3) \\
\hline Naphthalene(NaP) & $\begin{array}{r}\mathrm{ND}-0.031 \\
0.003 \pm 0.009\end{array}$ & $\begin{array}{r}\mathrm{ND}-0.022 \\
0.004 \pm 0.007\end{array}$ & $\begin{array}{r}\mathrm{ND} \\
0.000 \pm 0.0000\end{array}$ \\
\hline Acenaphthalene(AcpY) & $\begin{array}{r}\mathrm{ND}-0.043 \\
0.016 \pm 0.017\end{array}$ & $\begin{array}{r}\mathrm{ND}-0.031 \\
0.012 \pm 0.013\end{array}$ & $\begin{array}{r}\text { ND- }-0.060 \\
0.022 \pm 0.026\end{array}$ \\
\hline $\begin{array}{l}\text { Acenaphthene\& Flurene(AcP \& } \\
\text { Flu) }\end{array}$ & $\begin{array}{r}\text { ND-0.111 } \\
0.042 \pm 0.035\end{array}$ & $\begin{array}{r}\text { ND-0.081 } \\
0.029 \pm 0.030\end{array}$ & $\begin{array}{r}\text { ND-0.174 } \\
0.054 \pm 0.053\end{array}$ \\
\hline Phenanthrene(phen) & $\begin{array}{r}\mathrm{ND}-0.09 \\
0.020 \pm 0.032\end{array}$ & $\begin{array}{r}\text { ND-0.053 } \\
0.014 \pm 0.020\end{array}$ & $\begin{array}{r}\text { ND-0.063 } \\
0.023 \pm 0.0195\end{array}$ \\
\hline Anthracene(Ant) & $\begin{array}{r}\text { ND-0.033 } \\
0.011 \pm 0.0129\end{array}$ & $\begin{array}{r}\text { ND-0.06 } \\
0.010 \pm 0.0200\end{array}$ & $\begin{array}{r}\text { ND-0.031 } \\
0.009 \pm 0.0110\end{array}$ \\
\hline Flouranthene(Flur) & $\begin{array}{r}\text { ND- } 0.081 \\
0.043 \pm 0.0250\end{array}$ & $\begin{array}{r}\mathrm{ND}-0.081 \\
0.028 \pm 0.032\end{array}$ & $\begin{array}{r}\text { ND-0.08 } \\
0.0200 \pm 0.027\end{array}$ \\
\hline Pyrene(Py) & ND-0.121 & ND-0.101 & ND-0.061 \\
\hline Benzo(a)Anthracene(BaA) & ND-0.081 & ND-0.0301 & ND-0.011 \\
\hline Chrycene(Chry) & $\begin{array}{r}\text { ND- } 0.081 \\
0.039 \pm 0.0321\end{array}$ & $\begin{array}{r}\text { ND- } 0.080 \\
0.029 \pm 0.0310\end{array}$ & $\begin{array}{r}\text { ND-0.101 } \\
0.038 \pm 0.035\end{array}$ \\
\hline Benzo(b)Flouranthene(BbF) & $\begin{array}{r}\mathrm{ND}-0.063 \\
0.019 \pm 0.022\end{array}$ & $\begin{array}{r}\mathrm{ND}-0.081 \\
0.031 \pm 0.028\end{array}$ & $\begin{array}{r}\mathrm{ND}-0.051 \\
0.014 \pm 0.017\end{array}$ \\
\hline Benzo(k)Flouranthene(BkF) & $\begin{array}{r}0.021-0.233 \\
0.072 \pm 0.065\end{array}$ & $\begin{array}{r}0.011-0.313 \\
0.112 \pm 0.025\end{array}$ & $\begin{array}{r}\text { ND-0.060 } \\
0.015 \pm 0.026\end{array}$ \\
\hline Benzo(a)Pyrene(BaP) & $\begin{array}{r}\text { ND-0.210 } \\
0.072 \pm 0.0755\end{array}$ & $\begin{array}{r}\text { ND-0.080 } \\
0.021 \pm 0.029\end{array}$ & $\begin{array}{r}0.013-0.123 \\
0.046 \pm 0.034\end{array}$ \\
\hline Dibenzo(a,h)anthracene & $\begin{array}{r}0.051-0.181 \\
0.097 \pm 0.052\end{array}$ & $\begin{array}{r}0.010-0.211 \\
0.081 \pm 0.067\end{array}$ & $\begin{array}{r}\text { ND-0.102 } \\
0.043 \pm 0.031\end{array}$ \\
\hline Benzo(ghi)Perylene(BghiP) & $\begin{array}{r}0.03-0.211 \\
0.077 \pm 0.053\end{array}$ & $\begin{array}{r}0.03-0.280 \\
0.096 \pm 0.079\end{array}$ & $\begin{array}{r}0.010-0.100 \\
0.050 \pm 0.031\end{array}$ \\
\hline Indeno(1,2,3-cd)Pyrene(IND) & $\begin{array}{r}\text { ND-0.083 } \\
0.031 \pm 0.031\end{array}$ & $\begin{array}{r}\text { ND-0.103 } \\
0.039 \pm 0.045\end{array}$ & $\begin{array}{r}\text { ND-0.031 } \\
0.010 \pm 0.012\end{array}$ \\
\hline Total PAHs & $\begin{array}{r}0.150-1.432 \\
0.607 \pm 0.415\end{array}$ & $\begin{array}{r}0.081-1.462 \\
0.570 \pm 0.428\end{array}$ & $\begin{array}{r}0.080-0.941 \\
0.405 \pm 0.300\end{array}$ \\
\hline
\end{tabular}


Table(4):Some physiochemical properties of water samples at DWTPs (Efraz 1,2,3)

\begin{tabular}{|c|c|c|c|c|c|c|c|c|c|c|c|}
\hline \multicolumn{2}{|l|}{ Point } & \multicolumn{2}{|c|}{$\begin{array}{l}\text { Water } \\
\text { source }\end{array}$} & \multicolumn{2}{|c|}{ Flash mixer } & \multicolumn{2}{|c|}{$\begin{array}{l}\text { Sedimentation } \\
\text { (Clarifying) }\end{array}$} & \multicolumn{2}{|c|}{ Filteration } & \multicolumn{2}{|c|}{ Tap water } \\
\hline Properties & & T1 & T2 & T1 & $\mathbf{T} 2$ & T1 & T2 & T1 & T2 & T1 & $\mathbf{T 2}$ \\
\hline \multirow[t]{3}{*}{ PH } & El & 8.11 & 8.23 & 7.16 & 8.1 & 734 & 8.09 & 75 & 8.08 & 739 & 8.11 \\
\hline & E2 & 8.43 & 8.11 & 7.78 & 7.84 & 7.8 & 7.79 & 7.87 & 7.81 & 753 & 759 \\
\hline & E3 & 8.03 & 7.08 & 7.6 & 7.81 & 7.62 & 7.81 & 7.73 & 793 & 7.62 & 7.85 \\
\hline \multirow[t]{3}{*}{ E.C. } & El & 447 & 392 & 471 & 390 & 456 & 386 & 456 & 389 & 460 & 392 \\
\hline & E2 & 440 & 373 & 459 & 402 & 455 & 393 & 457 & 395 & 460 & 401 \\
\hline & E3 & 451 & 394 & 453 & 382 & 452 & 383 & 451 & 387 & 455 & 385 \\
\hline \multirow[t]{3}{*}{ Alkalinity } & El & 113 & 190 & 120 & 182 & 98 & 174 & 92 & 178 & 104 & 168 \\
\hline & E2 & 117 & 166 & 126 & 170 & 109 & 190 & 107 & 186 & 116 & 178 \\
\hline & E3 & 120 & 194 & 136 & 170 & 138 & 192 & 110 & 176 & 140 & 170 \\
\hline \multirow[t]{3}{*}{ Hardness } & El & 221 & 240 & 206 & 232 & 227 & 292 & 186 & 260 & 211 & 224 \\
\hline & E2 & 186 & 200 & 174 & 244 & 178 & 212 & 178 & 202 & 180 & 240 \\
\hline & E3 & 194 & 284 & 192 & 220 & 208 & 244 & 228 & 260 & 182 & 240 \\
\hline \multirow{3}{*}{$\begin{array}{l}\text { Calcium } \\
\text { hardness }\end{array}$} & El & 90 & 134 & 98 & 140 & 84 & 136 & 90 & 148 & 92 & 112 \\
\hline & E2 & 102 & 120 & 114 & 116 & 106 & 110 & 104 & 128 & 114 & 184 \\
\hline & E3 & 118 & 160 & 130 & 162 & 118 & 140 & 116 & 164 & 126 & 186 \\
\hline \multirow{3}{*}{$\begin{array}{c}\text { Dissohved } \\
\text { Oxygen }\end{array}$} & El & 70 & 9.7 & 6.4 & 10 & 7.6 & 10.8 & 6.8 & 11.2 & 8 & 10.8 \\
\hline & E2 & 7.8 & 109 & 70 & 11 & 7.4 & 11 & 7.2 & 10.4 & 8.2 & 10.1 \\
\hline & E3 & 7.2 & 10.4 & 6.0 & 103 & 7.6 & 10 & 3.2 & 12.8 & 6 & 12 \\
\hline \multirow[t]{3}{*}{ BOD5 } & El & 19 & 0.7 & 0.4 & 0.4 & 2.4 & 09 & 1.6 & 0.4 & 0.4 & 0.8 \\
\hline & E2 & 19 & 09 & 05 & 0.6 & 20 & 09 & 1.2 & 0.6 & 0.2 & 03 \\
\hline & E3 & 2.2 & 0.4 & 0.4 & 0.6 & 2.6 & 4 . 0 & 2.4 & 2.4 & 0.0 & 13 \\
\hline \multirow[t]{3}{*}{ CL- } & El & 173 & 16 & 17.6 & 20 & 21.1 & 16 & 18.1 & 16 & 18.1 & 16 \\
\hline & E2 & 16.6 & 16 & 18 & 18 & 223 & 16 & 16.0 & 18 & 253 & 24 \\
\hline & E3 & 18.1 & 16 & 18.8 & 22 & 210 & 20 & 18 & 18 & 23 & 20 \\
\hline
\end{tabular}

Table(3):The Mean concentration of PAHs compounds by ring at the DWTPs (Efraz 1,2,3)

\begin{tabular}{|c|c|c|c|c|c|c|c|c|c|c|}
\hline \multirow[t]{2}{*}{$\begin{array}{l}\text { PAHs } \\
\text { Com. }\end{array}$} & \multicolumn{2}{|c|}{$\begin{array}{r}\text { Raw water } \\
\text { (source) }\end{array}$} & \multicolumn{2}{|c|}{ Flash mixer } & \multicolumn{2}{|c|}{ clarifying } & \multicolumn{2}{|c|}{ filteration } & \multicolumn{2}{|c|}{ Tap wate } \\
\hline & Tl & T2 & Tl & T2 & Tl & T2 & Tl & $\mathbf{T} 2$ & Tl & T2 \\
\hline \multicolumn{11}{|c|}{ Water treatment plant station l(Efrax 1$)$} \\
\hline 2-ring & 0.04 & 0.03 & 0.04 & 0.04 & 0.03 & $0.0 \mathrm{r}$ & 0.0 & 0.0 & 0.01 & 0.0 \\
\hline 3-ring & 0.18 & 0.11 & 0.2 & 0.02 & 0.03 & 0.05 & 0.08 & 0.03 & 0.01 & 0.0 \\
\hline 4-ring & 030 & 0.25 & 0.23 & 0.11 & 0.16 & 0.11 & 0.14 & 0.11 & 0.04 & 0.0 \\
\hline 5-ring & 0.62 & 0.38 & 0.49 & 030 & 0.25 & 0.16 & 0.11 & 0.07 & 0.12 & 0.06 \\
\hline 6-ring & 039 & 0.13 & 0.14 & 0.14 & 0.08 & 0.08 & 0.09 & 0.05 & 0.05 & 0.03 \\
\hline \multicolumn{11}{|c|}{ Water tre atment plant station 2 (Efrax 2) } \\
\hline 2-ring & 0.03 & 0.03 & 0.03 & 0.03 & 0.0 & 0.02 & 0.0 & 0.0 & 0.01 & 0.01 \\
\hline 3-ring & 0.19 & 0.13 & 0.06 & 0.03 & 0.06 & 0.01 & 0.01 & 0.03 & 0.01 & 0.0 \\
\hline 4-ring & 0.27 & 0.18 & 0.17 & 0.11 & 0.25 & 0.07 & 0.11 & 0.12 & 0.13 & 0.01 \\
\hline 5-ring & 0.60 & 037 & 0.41 & 0.25 & 0.27 & 0.18 & 0.15 & 0.14 & 0.05 & 0.03 \\
\hline 6-ring & 038 & 0.19 & 0.23 & 0.13 & 0.07 & 0.08 & 0.05 & 0.05 & 0.05 & 0.03 \\
\hline \multicolumn{11}{|c|}{ Water tre atment plant station 3 (Efrax 3) } \\
\hline 2-ring & 0.03 & 0.05 & 0.06 & 0.0 & 0.06 & 0.02 & 0.0 & 0.0 & 0.0 & 0.0 \\
\hline 3-ring & 0.26 & 0.10 & 0.13 & 0.12 & 0.09 & 0.02 & 0.06 & 0.03 & 0.03 & 0.02 \\
\hline 4-ring & 035 & 0.17 & 0.13 & 0.13 & 0.06 & 0.06 & 0.06 & 0.01 & 0.03 & 0.0 \\
\hline 5-ring & 0.24 & 0.17 & 0.21 & 0.04 & 0.16 & 0.05 & 0.13 & 0.06 & 0.04 & 0.05 \\
\hline 6-ring & 0.13 & 0.08 & 0.06 & 0.08 & 0.07 & 0.06 & 0.03 & 0.04 & 0.04 & 0.01 \\
\hline
\end{tabular}




\section{$\underline{\text { Refernces }}$}

1.Doong, R. \& Lin, Y. (2004). Characterization and distribution of Polycyclic Aromatic hydrocarbon contaminations in surface sediment and water from Gao-Ping river, Taiwan.Water Research, 38: 1733-1744.

2.EHC-202(Environmental Health Crteria). (1998). Selected non-heterocyclic aromatic hydrocarbon.International Program on Chemical Safety.

3.Sander, M.; Sivertsen, S. and Scott, G. (2002). Origin \& distribution of Polycyclic Aromatic Hydrocarbon in surficial sediment from the Savanah river.Arch. Environ.Contam. Toxicol., 43: 438-448.

4.Brookes, J. (2004). London wide polycyclic Aromatic Hydrocarbons survey.Annulal report(2002-2003).

5.Basher, C., Obbard, J.P. and Lee, H.K. (2004). Persistent Organic pollutants in Singapores Coastal Marine Environment : part II, sediment.Water, Air \& Soil Pollution, 149(1-9): 315-325.

6.Akaishy, F.M., Silvade Assis, H.C., Lima, E. Jakobi, S.C.G., Scofield, A. and OliveiraRibeiro, C.A. (2004). Morphological and neurotoxicological finding in tropical fresh water fish(Asyana $s p$.) after water borne and acute exposure to water soluble fraction of crude oil.Archieve Environmental contamination Toxicology, 46: 244 -253.

7.Sarrazin, L.; Diana, C.; Wafo, E.; Lagadec, V.P.; Schembr, T. and Monod, J. L. (2006). Determination of Polycyclic Hydrocarbons(PAHs )in marine , Barakish , \& river sediments by HPLC, following Ulrtasonic Extraction.Liquid Chromatography \& related Technologies, 29(1): 69-85.

8.Neff, J.M. (1979). Polycyclic Aromatic Hydrocarbons in the aquatic environment , sources : fates \& biological effects.Applied Science puplishers LTD, London, UK. ISBN :0-85334-832-834pp.

9.Stackelberg,E.P.;Gibs,J; Furlong, T.E.; Meyer,T.M,; Zaugg,D,S and Lippincott,R.L.(2007).Efficiency of conventional drinking water treatment processes in removal of Pharmaaceutical and other organic compounds .Science of total Environment 377:222-272.

10. UNEP(UnitedNation Environmental Programm). (1989). Comparitive toxicity test of water accommodated fraction of oil dispersants to marine organisms. Reference methods for marine pollution , 45: $21 \mathrm{pp}$

11. Maskaoui, K.; Zhou, J.L.; Hong, H.S. and Zhang, Z.L. (2002). Contamination by Polycyclic Aromatic Hydrocarbons in the Jiulong river Estuary and Western Xiamen sea, China.Environmental pollution, 118: 109-122.

12. Simpson, C.D.; Mosi, A.A.; Cullen, W.R.and Reimer, K. (1996). Composition and Distribution of Polycyclic Aromatic Hydrocarbons in surficial marine sediment from Kitimat Harbour.Canada Science.Total Environment

13. Zakaria, M.P. ;Takada, H. ;Tutsumi, S. ; Ohno, K. ; Yamada, J. Kouno, E. and Kumata, H. (2002). Distribution of Polycyclic Aromatic Hydrocarbons (PAHs)in rivers and Estuaries in Malaysia : Awide spread input of petrogenic PAHs.Environmental Science \& Technology, 36: 107-118.

14. Brookes, K.M. (1997). Literature Review computer model and assessment of the potential Environmental risks associated with creosote treated wood products used in aquatic environment. Prepared for Western wood preservers institute.1-66 pp.

15. Vrana, B.; Pasch, A. and Popp, P. (2001). Polyaromatic Hydrocarbons concentrations and patterns in sediments and surface water of mansfed region, Saxony.Anhalt, Germany.J.Environm.Monit.3:602-609.

16. Moor, S.W. and Ramamoorthy, S. (1984). Organic chemicals in natural water in: Applied monitoring and Impact assessment.Springer, New York.

17. Volk,C.;Kaplan,L; Robinson,B; Hojnson,B; Wood,L and Zhu,H.(2005).Fluctuation of dissolved organic matter in river used for drinking water and impacts on conventional treatment plant performance .Environmental science and Technology.39:4258-64. 
18. Coupe, R. and Blomquist,J(2004).Watersoluble pesticides in finished water of community water supplies .JAWWA.96:56-68.

19. USEPA(2006)Ground water and Drinking water.www.epa.gov/safe water.1-3 pp.

20. EPA (Environmental Protection Agency ).(2004). 2004 Edition of drinking water standards and Health advisories. Washington,DC.1-20pp.

21. westerhoof,P; Yoon,Y; Snyder,S and Wert,E; (2005).Fate of endocrine -disruptor pharmaceutical , and personal care product chemicals during simulated drinking water treatment processes.Environmental science and Technology. 39:6649-63.
22. Crunkilton, R.L. \& DeVita, W.M. (1997)Determination of aqueous concentrations of Polycyclic Aromatic Hydrocarbons(PAHs)in an urbanstream.Chemosphere, 35(7): 14471463

23. WHO (1998). Polycyclic Aromatic Hydrocarbons.Guidelines for drinking water quality.second ed. Addendum to vol.2.Health Crieteria and other supporting information.World Health Organization, Geneva pp.123-152

24. USEPA(United State Environmental Protection Agency)(2007). Standars and health advisors.Hawthorne street,WTR6.San Francisco

\title{
كفاءة عمليات معالجة مياه الشرب في ازالة بعض مركبات ال PAHs من المياه في مدينة
}

(**** ميسون مهدي صالح الطائي

ك*** كلية العلوم - جامعةبابل

\author{
اربيل - العراق \\ (** سراج محمد عبداله كوران \\ * * (اواز بهروز محمد \\ * كلية العلوم - جامعة كركوك كلية العلوم - جامعة صلاح الدين
}

\section{الخلاصة}

جمعت نماذج مياه لكل مرحلة معالجة في محطات معالجة مياه الثرب ( DWTPs) في مدينة اربيل لدراسة ستة

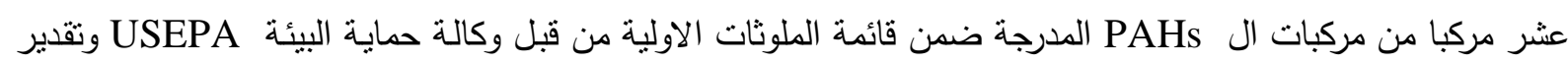

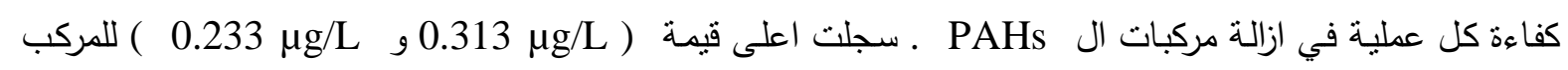

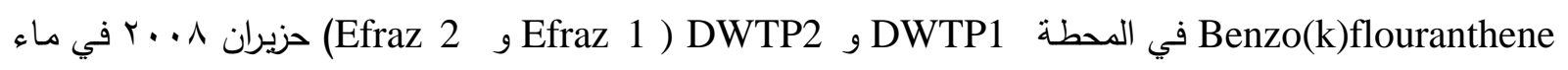

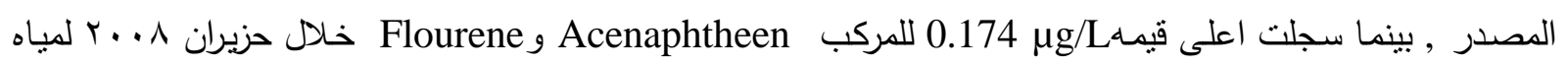

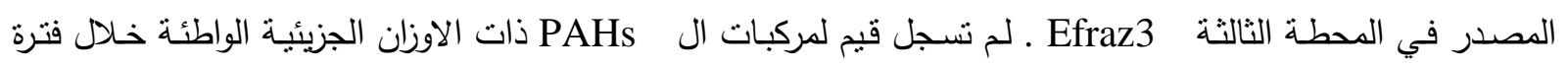
الدراسة لبعض مراحل معالجة المياه في الحطات DWTPs.تثير القيم الواطئة في مياه الحنفية (المياه المعالجة) الى كفاءة

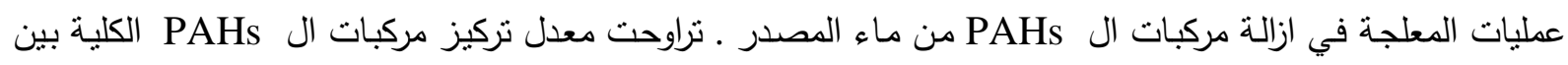

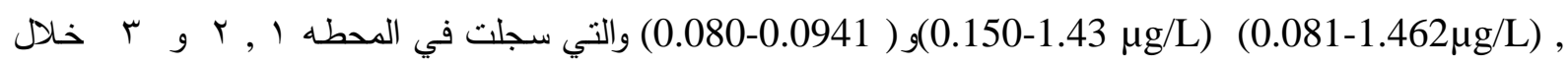

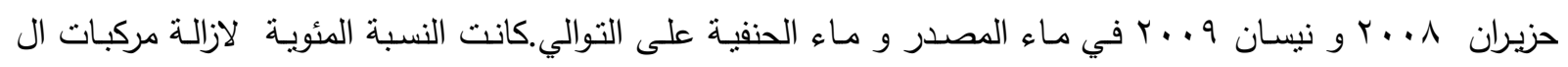

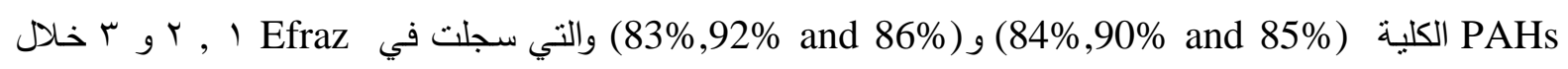

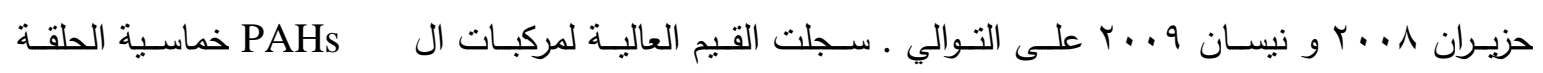

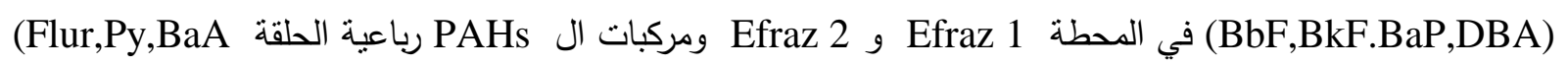
. Efraz في and chry) 